\title{
Pengaruh Pengetahuan terhadap Penggunaan Obat Parasetamol yang Rasional dalam Swamedikasi (Studi pada Ibu Rumah Tangga di Desa Sumberpoh Kecamatan Maron Kabupaten Probolinggo)
}

\author{
Elys Oktaviana $^{1}{ }^{*}$, Ika Ratna Hidayati ${ }^{1}$, Liza Pristianty ${ }^{2}$ \\ ${ }^{1}$ Departemen Farmasi, Fakultas Ilmu Kesehatan, Universitas Muhammadiyah Malang, Malang \\ ${ }^{2}$ Departemen Farmasi Komunitas, Fakultas Farmasi, Universitas Airlangga, Surabaya \\ *Corresponding author: elysoktaviana@gmail.com
}

\begin{abstract}
Background: The most commonly-used medication for self-medication was paracetamol. Paracetamol was used to relieve mild or moderate pain and mild-feverish conditions. Objective: To discover the effect of knowledge on the rational use of paracetamol in self-medication done by housewives in Sumberpoh Maron Probolinggo. Methods: This study used an analytically-observation method with cross-sectional study approach. The sample size was 84 respondents selected using purposive sampling. The instrument used closed questionnaires. The analysis used descriptive and simple linear regression method. Results: The study showed that the housewives' knowledge related to the rational use of paracetamol in self-medication was as follows good (39\%), quite good (51\%), less good (5\%), and not good (5\%). Housewives with positive action were (58\%), while $42 \%$ of them were with negative actions. The linear regression analysis showed significant value of $0.029<0.05, t$-count value $2.217>1.663, R$ square value $0.057, R$ value $(0.238)$, regression equation $Y=16.898+0.800 x$. Conclusion: Knowledge has effects on the rational use of paracetamol in self-medication done by housewives in Sumberpoh Maron Probolinggo. To improve public knowledge, especially housewives in Sumberpoh village, Maron Subdistrict, Probolinggo District, counseling about rational drug use in self-medication is suggested.
\end{abstract}

Keywords: knowledge, paracetamol, rational use of medicine

\begin{abstract}
Abstrak
Pendahuluan: Obat yang paling banyak digunakan untuk swamedikasi adalah parasetamol. Parasetamol digunakan untuk meredakan nyeri ringan atau sedang dan kondisi demam ringan. Tujuan: Mengetahui pengaruh pengetahuan terhadap penggunaan obat parasetamol yang rasional dalam swamedikasi pada ibu rumah tangga di Desa Sumberpoh Kecamatan Maron Kabupaten Probolinggo. Metode: Penelitian ini menggunakan metode observasi analitik dengan pendekatan studi cross-sectional. Jumlah sampel adalah 84 responden yang dipilih menggunakan purposive sampling. Instrumen yang digunakan adalah kuesioner tertutup. Analisis ini menggunakan metode regresi linier deskriptif dan sederhana. Hasil: Hasil penelitian yaitu ibu rumah tangga yang memiliki pengetahuan baik (39\%), cukup baik (51\%), kurang baik dan tidak baik masing-masing (5\%). Ibu rumah tangga dengan tindakan positif (58\%), sedangkan dengan tindakan negatif $(42 \%)$. Analisis regresi linier nilai signifikan $0,029<0,05$, nilai t-hitung $2,217>1,663$. Nilai Rsquare 0,057 , nilai $R(0,238)$, persamaan regresi $\mathrm{Y}=16,898+0,800 x$. Kesimpulan: Pengetahuan berpengaruh terhadap penggunaan obat parasetamol rasional dalam swamedikasi pada ibu rumah tangga di Desa Sumberpoh Kecamatan Maron Kabupaten Probolinggo. Untuk meningkatkan pengetahuan masyarakat, khususnya ibu rumah tangga di desa Sumberpoh, Kecamatan Maron, Kabupaten Probolinggo disarankan dilakukan penyuluhan tentang penggunaan obat parasetamol yang rasional dalam swamedikasi.
\end{abstract}

Kata kunci: pengetahuan, parasetamol, penggunaan obat rasional

\section{PENDAHULUAN}

Swamedikasi merupakan usaha pemilihan dan penggunaan obat modern, herbal, maupun obat tradisional oleh individu untuk mengatasi penyakit atau gejala penyakit (WHO, 1998). Swamedikasi sebaiknya mengikuti batasan penggunaan obat yang rasional (KemenKes RI, 2011). Prevalensi swamedikasi di daerah pedesaan $(81,5 \%)$ lebih besar dibandingkan 
dengan di daerah perkotaan (32,5\%) (Pandya dkk., 2013).

Pada penelitian Aqeel dkk., (2014) dilaporkan bahwa secara statistik tidak ditemukan perbedaan signifikan dalam penggunaan berbagai jenis obat analgesik antara penduduk perkotaan dan pedesaan. Golongan obat analgesik banyak digunakan dalam swamedikasi yaitu parasetamol sebesar $42,8 \%$, asam mefenamat sebesar 26,2\%, aspirin sebesar $16,0 \%$, ibuprofen sebesar 9,6\%, diklofenak sebesar 3,2\%, naproxen sebesar $1,1 \%$, dan flurbiprofen sebesar $1,1 \%$. Tarazi dkk. (2016) juga melaporkan bahwa obat yang banyak digunakan dalam swamedikasi adalah parasetamol 38,2\%, NSAID 29,1\%, Antibiotik 16,9\%, obat-obatan herbal 6,7\%, obat-obat lain 9,1\%. Parasetamol termasuk obat bebas yang banyak digunakan masyarakat sebagai analgetik dan antipiretik, karena relatif mudah didapatkan di apotek (Prescott, 1996). Bentuk sediaan tablet lebih disukai untuk swamedikasi sebesar 83,2\% (Bollu dkk., 2014). Hasil penelitian Molloy dkk. (2016) ditemukan bahwa pemerintah Inggris menemukan bahwa tidak lebih dari 100 tablet/kapsul/kaplet (500 mg parasetamol dan 7,5 $30 \mathrm{mg}$ aspirin) dapat terjual setiap toko eceran atau apotek dalam satu transaksi. Penggunaan parasetamol cenderung aman ketika sesuai dengan takarannya dan dapat menimbulkan hepatotoksik pada pemakaian lebih dari 4 gram (Larson, dkk., 2005). Di Amerika, lembaga Food and Drug Administration (FDA) mencatat sebanyak 307 kasus hepatotoksik yang berkaitan dengan penggunaan parasetamol dari Januari 1998 hingga 2001. Sebanyak $60 \%$ penderita hepatotoksik dikategorikan sebagai pasien gagal hati parah, sedangkan $40 \%$ penderita meninggal dunia. Reaksi pada kulit dan hipersensitivitas lain dilaporkan pernah terjadi meski jarang terjadi (AHFS, 2005).

Menurut konsep perilaku Green \& Kreuter (1991) pengetahuan merupakan salah satu faktor dari predisposisi yang berpengaruh terhadap kesehatan seseorang. Menurut Notoatmodjo (2007), pengetahuan adalah hasil dari tahu, dan terjadi setelah orang melakukan penginderaan terhadap suatu objek tertentu. Penelitian yang dilakukan Wulandari (2011) terkait tingkat pengetahuan penggunaan analgetik pada pengobatan sendiri di Klaten menunjukkan hasil penilaian pengetahuan responden sebesar $65,6 \%$ dengan kategori cukup dan $34,4 \%$ baik. Hasil penelitian yang dilakukan Gupta dkk. (2011) persentase yang melakukan swamedikasi berdasarkan jenis kelamin wanita sebesar 69,2\% sedangkan lakilaki sebesar 30,8\%. Penelitian di Kecamatan Tanjung
Bintang Kabupaten Lampung Selatan hanya 46,1\% ibu-ibu melakukan pengobatan sendiri yang sesuai aturan (Supardi dkk., 2002). Berdasarkan Badan pusat Statistik atau BPS (2015) daerah Kecamatan Maron yang menunjukkan bahwa di Desa Sumberpoh hanya tersedia Polindes dan toko sebanyak 23 serta 17 warung. Dalam hal ini memungkinkan ibu rumah tangga di Desa Sumberpoh dapat melakukan pengobatan sendiri sehingga perlu dilakukan penelitian tentang pengaruh pengetahuan terhadap penggunaan obat parasetamol rasional dalam swamedikasi pada ibu rumah tangga di Desa Sumberpoh Kecamatan Maron Kabupaten Probolinggo, dengan tujuan untuk mengetahui pengaruh pengetahuan terhadap penggunaan obat parasetamol rasional dalam swamedikasi.

\section{METODE}

Pada penelitian ini menggunakan metode crosssectional dimana pengambilan sampel dilakukan dengan metode purposive sampling. Populasi dalam penelitian ini adalah semua ibu rumah tangga yang berada di Desa Sumberpoh yang berumur 18 - 50 tahun. Kriteria inklusi adalah ibu rumah tangga yang menetap dan sudah terdaftar dalam data penduduk Desa Sumberpoh yang menggunakan obat parasetamol (semua jenis obat yang mengandung parasetamol dengan dosis 325 - $650 \mathrm{mg}$ dalam bentuk sediaan tablet, kapsul, dan kaplet) secara swamedikasi maksimal 1 bulan waktu terakhir penggunaanya. Desa Sumberpoh terdiri dari 6 dusun (10 RT). Jumlah sampel ditentukan dengan menggunakan rumus Slovin, diperoleh 84 ibu rumah tangga. Jumlah sampel ini kemudian dibagi secara proporsional berdasarkan (6 dusun atau 10 RT) yang ada di Desa Sumberpoh.

Variabel independen dalam penelitian ini adalah tingkat pengetahuan ibu rumah tangga di Desa Sumberpoh dalam swamedikasi mengenai pemilihan obat, dosis (jumlah obat, cara pemberian obat, interval waktu pemberian obat, lama pemberian obat), penyimpanan obat, efek samping obat, dan tindak lanjut. Kategori penilaian yaitu: Baik (76\% - 100\%), cukup baik (56\%-75\%), kurang baik (40\%-55\%), dan tidak baik $(<40 \%)$. Sedangkan variabel dependen adalah penggunaan obat parasetamol rasional dalam swamedikasi ibu rumah tangga di Desa Sumberpoh. Tindakan penggunaan obat parasetamol adalah perilaku yang diamati, yaitu meliputi tepat indikasi penyakit, tepat dosis (tepat jumlah, tepat cara pemberian, tepat interval waktu pemberian, tepat lama pemberian), penyimpanan, tepat tindak lanjut, sehingga diperoleh 
dua kategori yaitu: tindakan positif dan tindakan negatif. Kedua variabel tersebut dianalisa dengan menggunakan uji regresi linier sederhana untuk mengetahui adanya pengaruh variabel pengetahuan (independen) terhadap variabel tindakan (penggunaan obat parasetamol rasional) (dependen).

Instrumen yang digunakan adalah kuesioner tertutup. Kuisioner ini digunakan untuk mengetahui tingkat pengetahuan dan tindakan (penggunaan obat parasetamol rasional) dalam swamedikasi, untuk kuisioner pengetahuan menggunakan skala Guttman, sedangkan kuisioner tindakan dalam swamedikasi menggunakan skala Likert. Instrumen tersebut dilakukan uji validitas dan reliabilitas sebelum digunakan pada responden penelitian. Kisi-kisi instrumen dapat dilihat pada Tabel 1 dan untuk definisi operasional variabel dapat dilihat dalam Tabel 2 .

Tabel 1. Kisi-kisi instrumen

\begin{tabular}{|c|c|c|}
\hline Variabel Penelitian & Indikator & No.item \\
\hline $\begin{array}{l}\text { Tingkat pengetahuan ibu } \\
\text { rumah tangga tentang } \\
\text { swamedikasi obat } \\
\text { parasetamol }\end{array}$ & $\begin{array}{l}\text { 1. Pemilihan Obat } \\
\text { 2. Dosis } \\
\text { 1) Jumlah obat } \\
\text { 2) Cara pemberian obat } \\
\text { 3) Interval waktu pemberian obat } \\
\text { 4) Lama pemberian obat } \\
\text { 3. Penyimpanan obat } \\
\text { 4. Efek samping obat } \\
\text { 5. Tindak lanjut }\end{array}$ & $\begin{array}{c}2 \\
3 \\
4 \\
5,6 \\
7 \\
8 \\
9\end{array}$ \\
\hline $\begin{array}{l}\text { Penggunaan obat } \\
\text { parasetamol rasional dalam } \\
\text { swamedikasi pada ibu } \\
\text { rumah tangga }\end{array}$ & $\begin{array}{l}\text { 1. Tepat Pemilihan Obat } \\
\text { 2. Tepat Dosis } \\
\text { 1) Tepat jumlah obat } \\
\text { 2) Tepat cara pemberian } \\
\text { 3) Tepat interval waktu pemberian } \\
\text { 4) Tepat lama pemberian } \\
\text { 3. Tepat penyimpanan obat } \\
\text { 4. Tepat tindak lanjut }\end{array}$ & $\begin{array}{c}2 \\
3 \\
4 \\
5,6 \\
7 \\
8\end{array}$ \\
\hline
\end{tabular}

Tabel 2. Definisi operasional variabel

\begin{tabular}{|c|c|c|c|}
\hline \multicolumn{4}{|c|}{ Variabel Pengetahuan tentang Swamedikasi Obat Parasetamol Rasional } \\
\hline Defini Operasional & Skala Data & Alat Ukur & Kategori \\
\hline $\begin{array}{l}\text { Tingkat pengetahuan Ibu rumah } \\
\text { tangga tentang swamedikasi obat } \\
\text { parasetamol rasional mencakup: } \\
\text { 1. Pemilihan Obat } \\
\text { 2. Dosis } \\
\text { 1) Jumlah obat } \\
\text { 2) Cara pemberian obat } \\
\text { 3) Interval waktu pemberian } \\
\text { obat } \\
\text { 4) Lama pemberian obat } \\
\text { 3. Penyimpanan obat } \\
\text { 4. Efek samping obat } \\
\text { 5. Tindak lanjut }\end{array}$ & $\begin{array}{l}\text { Ordinal } \\
\text { Ciri-ciri skala } \\
\text { ordinal adalah } \\
\text { 1. Terdiri dari } \\
\text { beberapa } \\
\text { kategori } \\
\text { 2. Antara } \\
\text { kategori yang } \\
\text { satu dengan } \\
\text { yang lainnya } \\
\text { dapat } \\
\text { dibedakan }\end{array}$ & $\begin{array}{l}\text { Kuisioner tingkat } \\
\text { pengetahuan yang } \\
\text { terdiri } 9 \text { pertanyaan }\end{array}$ & $\begin{array}{l}\text { Dilakukan penilaian terhadap } \\
\text { kuesioer. hasil yang diperoleh } \\
\text { dikelompokkan menjadi } \\
\text { kategori : } \\
\text { 1. Baik } \\
\quad(76 \%-100 \%) \\
\text { 2. Cukup } \\
\quad(56 \%-75 \%) \\
\text { 3. Kurang Baik } \\
(40 \%-55 \%) \\
\text { 4. Tidak Baik } \\
(<40 \%)\end{array}$ \\
\hline
\end{tabular}

\begin{tabular}{|c|c|c|c|}
\hline \multicolumn{4}{|c|}{ Variabel Tindakan (Penggunaan Obat Parasetamol Rasional) } \\
\hline Defini Operasional & Skala Data & Alat Ukur & Kategori \\
\hline Perilaku swamedikasi obat & Nominal & Kuesioner tindakan & Dilakukan penilaian terhadap \\
\hline parasetamol yang rasional pada & Data nominal atau & dengan Teknik & kuesioner. Hasil yang diperoleh \\
\hline ibu rumah tangga meliputi: & disebut juga & Skala & dikelompokkan menjadi 2 \\
\hline 1. Pemilihan Obat & dengan & kuesioner terdiri & kategori : \\
\hline 2. Dosis & kategorikal, & dari 8 pertanyaan & 1. Tindakan Positif \\
\hline 1) Tepat jumlah obat & terdiri dari & & Bila skor $-\mathrm{T} \geq$ mean $\mathrm{T}$ \\
\hline 2) Tepat cara pemberian & kategori & & kelompok. \\
\hline 3) Tepat interval waktu & lebih. & & 2. Tindakan Negatif \\
\hline 4) Tepat lama pemberian & & & Bila skor $-\mathrm{T} \leq$ mean $\mathrm{T}$ \\
\hline 3. Tepat penyimpanan obat & & & kelompok. \\
\hline 4. Tepat tindak lanjut & & & \\
\hline
\end{tabular}




\section{Uji validitas dan reliabilitas}

Uji validitas dan reliabilitas pada penelitian ini menggunakan SPSS (Statistical Product and Service Solutions) ver. 16 for windows. Kriteria instrument valid apabila nilai probabilitas korelasi [sig. (2-tailed)] $<$ taraf signifikan $(\alpha)$ sebesar 0,05 (Juliandi, 2007). Butir pertanyaan dikatan valid apabila nilai $\mathrm{r}$ hitung $>\mathrm{r}$ tabel. Sedangkan untuk nilai reliabilitas dapat membandingkan Nilai Cronbach's Alpha yang diperoleh dengan Tabel 3. Dasar pengambilan keputusaan jika nilai Alpha > 0,60 maka reliable (Juliandi, 2007).

Tabel 3. Tingkat reliabilitas berdasarkan nilai alpha (Sujianto, 2007)

\begin{tabular}{cc}
\hline Alpha & Tingkat Reliabilitas \\
\hline $0,0-0,20$ & Kurang reliabel \\
$>0,20-0,40$ & Agak reliabel \\
$>0,40-0,60$ & Cukup reliabel \\
$>0,60-0,80$ & Reliabel \\
$>0,80-1,00$ & Sangat reliabel \\
\hline
\end{tabular}

\section{Penilaian tingkat pengetahuan}

Penilaian tingkat pengetahuan menggunakan skala Guttman yang setiap satu item pertanyaan yang dijawab "Ya" maka diberi skor 1 dan jika di jawab "Tidak" diberi skor 0 , kemudian dimasukkan kedalam rumus:

$$
\mathrm{P}=\mathrm{F} / \mathrm{n} \times 100 \%
$$

Keterangan:

$\mathrm{P}=$ nilai prosentase

$\mathrm{F}=$ Jawaban benar

$\mathrm{n}=$ Jumlah soal

(Sugiono, 2014)

\section{Penilaian tindakan (penggunaan obat parasetamol rasional)}

Indikator untuk menentukan sifat tindakan ibu rumah tangga dengan menggunakan Model Likert yang terdiri dari empat alternatif jawaban yaitu, apabila di jawab Selalu (SL) maka nilainya 4, Sering (SR) nilainya 3, Kadang-kadang (KD) nilainya 2, Tidak pernah (TP) nilainya 1. Dalam menjawab Skala Likert, responden hanya memberi tanda centang $(\sqrt{ })$ pada kemungkinan jawaban yang paling sesuai dengan pribadinya, kemudian dari hasil scoring tersebut dimasukkan rumus:

$$
\mathrm{T}=50+10[(\mathrm{X}-\overline{\mathrm{x}}) / \mathrm{s}]
$$

Keterangan:

$\mathrm{X}$ : skor responden pada skala tindakan yang akan diubah menjadi skor $\mathrm{T}$

$\overline{\mathrm{x}}$ : mean skor kelompok

$\mathrm{s}$ : standar deviasi kelompok
Tindakan positif jika skor $\mathrm{T} \geq$ mean

Tindakan negatif jika skor $\mathrm{T}<$ mean

(Azwar, 2011).

Perhitungan skor $\mathrm{T}$ menggunakan bantuan program SPSS (Statistical Product and Service Solutions) ver. 16 for windows.

\section{HASIL DAN PEMBAHASAN}

\section{Hasil uji validitas dan reliabilitas}

Berikut Tabel 4 yang menyajikan hasil uji validitas pengetahuan dan tindakan.

Tabel 4. Hasil uji validitas pengetahuan dan tindakan

\begin{tabular}{cccc}
\hline \multicolumn{4}{c}{ Pengetahuan } \\
\hline $\begin{array}{c}\text { No. } \\
\text { item }\end{array}$ & r hitung & r tabel & keterangan \\
\hline 1 & 0,767 & 0,361 & Valid \\
\hline 2 & 0,510 & 0,361 & Valid \\
3 & 0,703 & 0,361 & Valid \\
4 & 0,510 & 0,361 & Valid \\
5 & 0,439 & 0,361 & Valid \\
6 & 0,363 & 0,361 & Valid \\
7 & 0,581 & 0,361 & Valid \\
8 & 0,651 & 0,361 & Valid \\
9 & 0,581 & 0,361 & Valid \\
\hline \multicolumn{4}{c}{ Tindakan } \\
\hline No. & r hitung & r tabel & keterangan \\
item & & & \\
\hline 1 & 0,946 & 0,361 & Valid \\
2 & 0,392 & 0,361 & Valid \\
3 & 0,836 & 0,361 & Valid \\
4 & 0,392 & 0,361 & Valid \\
5 & 0,704 & 0,361 & Valid \\
6 & 0,392 & 0,361 & Valid \\
7 & 0,565 & 0,361 & Valid \\
8 & 0,699 & 0,361 & Valid \\
\hline
\end{tabular}

Hasil analisis uji validitas dari 30 ibu rumah tangga untuk variabel pengetahuan dan variabel tindakan dinyatakan valid dimana nilai $r$ hitung $>r$ tabel.

Tabel 5. Hasil uji reliabilitas

\begin{tabular}{ccc}
\hline Variabel & $\begin{array}{c}\text { Alpha } \\
\text { Cronbach }\end{array}$ & Keterangan \\
\hline Pengetahuan & 0,747 & Reliabel \\
Tindakan & 0,802 & Reliabel \\
\hline
\end{tabular}

Sedangkan uji reliabilitasnya untuk variabel pengetahuan dan variabel tindakan dapat dilihat pada Tabel 2 yang menunjukkan nilai Alpha Cronbach lebih besar dari 0,6.

\section{Karakteristik ibu rumah tangga di Desa Sumberpoh}

Ibu rumah tangga di Desa Sumberpoh paling banyak yang melakukan swamedikasi obat parasetamol 
pada interval usia 30 - 36 tahun sebesar $30 \%$ (25 orang). Pendidikan terakhir paling banyak adalah tamat $\mathrm{SD} /$ sederajat sebesar $40 \%$ (34 orang), dan paling banyak ibu rumah tangga yang tidak bekerja sebesar $80 \%$ (67 orang). Obat yang paling banyak digunakan oleh ibu rumah tangga dalam swamedikasi adalah obat dengan nama dagang Bodrex ${ }^{\circledR}$ sebesar $71 \%$ (60 orang), dengan sediaan obat paling banyak dalam bentuk tablet sebesar $81 \%$. Ibu rumah tangga yang menggunakan obat parasetamol dengan keluhan tertinggi adalah sakit kepala sebesar $84 \%$ (71 orang). Waktu penggunaan terakhir obat parasetamol paling banyak adalah 1 minggu yang lalu yaitu sebesar $29 \%$ (24 orang). Ibu rumah tangga paling banyak membeli obat parasetamol di toko/warung kelontong sebesar 94\% (79 orang). Berdasarkan rekapitulasi nilai pengetahuan ibu rumah tangga yang mendapat nilai 8 sebesar 20\% (17 orang), yang mendapat nilai 7 sebesar 19\% (16 orang), nilai 6 sebesar 24\% (20 orang), yang mendapat nilai 3 (33\%) dan 4 (44\%) masing-masing sebesar 5\% (4 orang), dari rekapitulasi nilai di atas dapat menggolongkan kategori pengetahuan ibu rumah tangga berdasarkan ketentuan yang telah ditetapkan. Berdasarkan Tabel 6 menunjukkan bahwa kategori tingkat pengetahuan ibu rumah tangga meliputi baik sebesar 39\% (33 orang), cukup baik $51 \%$ (43 orang), untuk kategori pengetahuan kurang baik dan tidak baik masingmasing sebesar $5 \%$ (4 orang).

Tabel 6. Kategori tingkat pengetahuan ibu rumah

\begin{tabular}{ccc}
\multicolumn{3}{c}{ tangga } \\
\hline Pengetahuan & Frekuensi & Persentase (\%) \\
\hline Baik & 33 & 39 \\
Cukup Baik & 43 & 51 \\
Kurang Baik & 4 & 5 \\
Tidak Baik & 4 & 5 \\
\hline Jumlah & 84 & 100 \\
\hline Tabel 7. Kategori tindakan ibu rumah tangga \\
\hline Tindakan & Frekuensi & Persentase $(\%)$ \\
\hline Positif & 49 & 58 \\
Negatif & 35 & 42 \\
\hline Jumlah & 84 & 100 \\
\hline
\end{tabular}

Berdasarkan rekapitulasi nilai tindakan ibu rumah tangga dalam Swamedikasi yang mendapat nilai dengan interval 30 - 39 sebesar 22\% (18 orang), 40 - 49 sebesar $20 \%$ (17 orang), 50 - 59 sebesar $42 \%$ (35 orang), 60 - 69 sebesar 14\% (12 orang), sedangkan yang mendapat nilai 70 - 79 sebesar $2 \%$ (2 orang), dari rekapitulasi nilai tindakan dapat menentukan kategori dari tindakan ibu rumah tangga berdasarkan ketentuan yang telah di tentukan. Berdasarkan Tabel 7 menunjukkan bahwa tindakan ibu rumah tangga dengan kategori negatif sebesar $42 \%$ (35 orang), sedangkan dengan kategori positif sebesar $58 \%$ (49 orang).

\section{Analisis regresi linier sederhana Uji normalitas}

Berdasarkan hasil analisis uji linearitas diketahui bahwa nilai signifikan sebesar 0,666 yang lebih besar dari 0,05 , sehingga dapat dinyatakan data berdistribusi normal.

\section{Uji linieritas}

Hasil uji linearitas pada Tabel 8 diperoleh nilai signifikan 0,969 lebih besar dari 0,05 yang artinya terdapat hubungan linier secara signifikan antara variabel $\mathrm{X}$ (pengetahuan) dengan variable $\mathrm{Y}$ (Tindakan).

Tabel 8. Uji Linearitas

\begin{tabular}{cc}
\hline Signifikan Hasil & Signifikan \\
\hline 0,969 & 0,05 \\
\hline
\end{tabular}

\section{Regresi linier sederhana}

Berikut merupakan Tabel 9 yang merupakan hasil dari analisis regresi linier sederhana.

Tabel 9. Hasil Analisis Regresi Linier Sederhana

\begin{tabular}{ccc}
\hline No. & Hasil Analisis & Nilai \\
\hline 1. & Nilai Signifikan & 0,029 \\
2. & T hitung & 2,217 \\
3. & R & 0,238 \\
4. & R Square & 0,057 \\
5. & Persamaan & $\mathrm{Y}=16,898+0,800 \mathrm{x}$ \\
& Regresi & \\
\hline
\end{tabular}

Hasil analisis regresi linier dalam Tabel 9 menunjukkan nilai signifikan 0,029 yang berarti $<0,05$, dan nilai t-hitung 2,217 dibandingkan dengan t-tabel $(1,663)$ berarti t-hitung > t-tabel maka $\mathrm{H}_{0}$ ditolak, $\mathrm{H}_{1}$ diterima, yang artinya ada pengaruh pengetahuan terhadap penggunaan obat parasetamol rasional dalam swamedikasi pada ibu rumah tangga di Desa Sumberpoh Kecamatan Maron Kabupaten Probolinggo.

Nilai $\mathrm{R}$ yang diperoleh melalui analisis regresi linier merupakan simbol dari koefisien korelasi sebesar 0,238 . Nilai $\mathbf{R}$ tersebut dibandingkan dengan Tabel 4 dan dikategorikan memiliki korelasi yang lemah.

Selain nilai $\mathrm{R}$ juga diperoleh nilai $\mathrm{R}$ square atau Koefisien Determinasi (KD) dengan nilai sebesar $5,7 \%$. Nilai $\mathrm{R}$ square menunjukkan bahwa pengetahuan memiliki pengaruh sebesar $5,7 \%$ terhadap penggunaan obat parasetamol rasional dalam swamedikasi, sedangkan $94,3 \%$ di pengaruhi oleh faktor-faktor lain di luar variabel bebas. Hasil penelitian Kaushal dkk., (2012) menunjukkan bahwa 
ibu rumah tangga melakukan swamedikasi didasari oleh resep sebelumnya $49 \%$, iklan di koran dan televisi $26 \%$, informasi dari teman $17 \%$, dan lain-lain $8 \%$. Hasil penelitian Ahmed dkk. (2014) menunjukkan bahwa sumber yang paling umum dari informasi untuk melakukan pengobatan sendiri adalah saran dari keluarga, teman, dan tetangga. Hal ini didukung juga oleh penelitian yang dilakukan Setyawati (2012), menjelaskan bahwa pemilihan obat analgetik antipiretik pada masyarakat di Kelurahan Pondok Karanganom Klaten salah satunya didasari oleh adanya informasi tentang obat analgetik antipiretik dapat diperoleh dari iklan media massa sebesar 84\%, pengalaman teman/keluarga $14 \%$, petugas kesehatan $0 \%$ dan leaflet/kemasan obat 2\%. Proporsi swamedikasi yang tinggi di pedesaan umumnya karena kurangnya fasilitas kesehatan dan faktor ekonomi (Aqeel dkk., 2014). Dijelaskan oleh Lawrence Green dalam (Notoatmodjo, 2003) bahwa perilaku itu sendiri dipengaruhi oleh 3 faktor yaitu faktor predisposisi yang terwujud dalam bentuk (pengetahuan, nilai, sikap, dan persepsi yang berhubungan dengan motivasi individu ataupun kelompok dalam masyarakat, ada faktor pendukung seperti lingkungan fisik, tersedia atau tidak tersedianya fasilitas kesehatan misalnya puskesmas, obat-obatan, sekolah kesehatan. faktor pendorong yang terwujud dalam sikap dan perilaku petugas kesehatan atau petugas lain yang termasuk dalam kelompok referensi dari perilaku masyarakat.

Model persamaan regresi yang diperoleh yaitu $\mathrm{Y}=16,898+0,800 \mathrm{x}$ yang berarti penggunaan obat parasetamol rasional dalam swamedikasi oleh ibu rumah tangga di Desa Sumberpoh Kecamatan Maron Kabupaten Probolinggo (y) akan meningkat sebesar 0,800 satuan untuk setiap peningkatan pengetahuan (x). Dengan kata lain, apabila pengetahuan ibu rumah tangga mengalami peningkatan 1 satuan maka penggunaan obat parasetamol rasional dalam swamedikasi yang dilakukan oleh ibu rumah tangga akan mengalami peningkatan sebesar 0,800 satuan, sehingga tindakan (penggunaan obat parasetamol rasional) dalam swamedikasi sebesar 17,698 satuan.

Nilai a pada persamaan regresi linier menunjukkan bahwa apabila variabel pengetahuan mempunyai nilai 0 satuan maka penggunaan obat parasetamol rasional sebesar 16,898 satuan.

Persamaan tersebut juga menunjukkan bahwa pengetahuan memiliki pengaruh yang positif terhadap penggunaan obat parasetamol rasional dalam swamedikasi pada ibu rumah tangga dengan nilai $b$ (koefisien regresi) yang positif.

\section{KESIMPULAN}

Berdasarkan hasil penelitian yang telah dilakukan maka dapat disimpulkan bahwa:

1. Tingkat pengetahuan ibu rumah tangga dalam swamedikasi obat parasetamol berada pada kategori baik sebesar 39,29\% (33 orang), cukup baik sebesar $51,19 \%$ (43 orang), kurang baik dan tidak baik masing-masing 4,76\% (4 orang).

2. Ibu rumah tangga dengan tindakan positif dalam swamedikasi obat parasetamol sebesar 58\% (49 orang), sedangkan dengan tindakan negatif sebesar 41,67\% (35 orang).

3. Pengetahuan berpengaruh sebesar $5,7 \%$ terhadap penggunaan obat parasetamol rasional dalam swamedikasi pada ibu rumah tangga di Desa Sumberpoh Kecamatan Maron Kabupaten Probolinggo dan 94,3\% lainnya adalah faktor-faktor lain diluar variabel pengetahuan dengan nilai signifikan 0,029 dan nilai t-hitung 2,217> t-tabel (1,663).

\section{UCAPAN TERIMA KASIH}

Penelitian ini adalah bagian dari skripsi yang diajukan untuk memenuhi syarat mencapai gelar Sarjana Famasi, pada Program Studi Farmasi Fakultas Ilmu Kesehatan Universitas Muhammadiyah Malang. Penulis mengucapkan terimakasih banyak kepada Kepala Desa dan semua ibu rumah tangga di Desa Sumberpoh Kecamatan Maron Kabupaten Probolinggo yang telah bersedia menjadi sampel penelitian ini.

\section{DAFTAR PUSTAKA}

AHFS. (2005). Drug Information, American Society of Health-System Pharmacists. Maryland: ASHP.

Ahmed, A., Patel, I., Mohanta, G. P. \& Balkrishnan, R. (2014). Evaluation of Self Medication Practices in Rural Area of Town Sahaswan at Northern India. Annals of Medical and Health Science Research; 4; 73-78.

Aqeel, T., Shabbir, S., Basharat, H., Bukhori, M., Mobin, S., Shahid, H. \& Waqar, S. A. (2014). Prevalence of Self-Medication among Urban and Rural Population of Islamabad, Pakistan. Tropical Journal of Pharmaceutical Research; 13; 627-633.

Azwar, S. (2011). Metode Penelitian. Yogyakarta: Pustaka Pelajar.

Bollu, M., Vasanthi, B., Chowdary., P. S., Chaitanya, D. S., Nirojini, P. S. \& Nadendla, R. R. (2014). Prevalence of Self Medication among the Pharmacy Student In Guntur: A Questionnaire 
based Study. World Journal of Pharmacy and Pharmaceutical Science; 3; 810-826.

Badan Pusat Statistik (BPS). (2015). Statistik Daerah Kecamatan Maron. Probolinggo: Badan Pusat Statistik Kabupaten Probolinggo.

Juliandi, A. (2007). Teknik Pengujian Validitas dan Reabilitas by Azuar Juliandi. https://marsonobejosuwito.files.wordpress.com/ 2011/04/spss_3.pdf. Accessed: 09 April 2017.

Green, L. W. \& Kreuter M. W. (1991). Heath Promotion Planning, an Educational and Environmental Approuch. California: Mayfield Publishing Co.

Gupta, P., Prateeks., Bobhate., Saurabh, R. \& Shrivastava. (2011). Determinants of Selfmedication Practices in an Urban Slum Community. Asian Journal of Pharmaceutical and Clinical Research; 4; 54-57

Kaushal, J., Gupta, M. C. \& Verma, S. (2012). SelfMedication Patterns and Drug Use Behavior in Housewives Belonging to the Middle Income Group in a City in Northern India. Indian Journal of Community Medicine; 37; 16-19.

Kementrian Kesehatan Republik Indonesia (KemenKes RI). (2011). Penggunaan Obat Rasional. Jakarta: Kementrian Kehatan RI.

Larson, A. M., Polson, J., Fontana, R. J., Davern, T. J., Lalani, E., Hynan, L. S., Reisch, J. S., Schiødt, F. V., Ostapowicz, G., Shakil, A. O. \& Lee, W. M. (2005). Acetaminophen-Induced Acute Liver Failure: Result of a United States Multicenter, Prospective Study. Hepatology; 42; 1364-1372.

Molloy, P., Chambers, R. \& Cork, T. (2016). How Well are National Guidelines Relating to the General Sales of Aspirin and Paracetamol, Adhered to by Retail Stores: a Mystery Shopper Study. London: BMJ Open.
Notoatmodjo, S. (2003). Pendidikan dan Perilaku Kesehatan. Jakarta: Rineka Cipta.

Notoatmodjo, S. (2007). Promosi dan Perilaku Kesehatan. Jakarta: Rineka Cipta.

Pandya, R. N., Jhaveri, K. S, Vyas, F. I. \& Patel, V. J. (2013). Prevalence, Pattern and Perceptions of Self-medication in Medical Student. International Journal of Basic and Clinical Pharmacology; 2; 275-280.

Prescott, L. F. (1996). Paracetamol (Acetaminophen): A Critical Bibliographic Review (1st Ed.). London: Taylor \& Francis.

Setyawati, E. (2012). Evaluasi Penggunaan Obat Analgetik Antipiretik sebagai Upaya Pengobatan Sendiri di Kelurahan Pondok Karanganom Klaten. Skripsi; Fakultas Farmasi Universitas Muhammadiyah, Surakarta.

Sujianto A. (2009). Aplikasi Statistik dengan SPSS 16.0. Jakarta: PT Prestasi Pustakaraya.

Supardi, S., Sampurno, O. D. \& Notosiswoyo M. (2002). Pengobatan Sendiri yang Sesuai dengan Aturan pada Ibu-Ibu di Jawa Barat. Buletin Penelitian Kesehatan; 30; 11-21.

Tarazi, S., Almaaytah, A., Laham, N. A., Ayesh, B. \& Arafat, H. (2016). Prevalence of Self Medication Practice among Al-Azhar Medical Laboratory University Student Gaza Strip. Indian Journal of Research; 5; 231-234.

World Health Organization (WHO). (1998). The Role of Pharmacist in Self-care and Self-medication: Report of the $4^{\text {th }}$ WHO Consultative Group on the Role of Pharmacist. Geneva: WHO.

Wulandari, I. S. (2011). Perbedaan Tingkat Pengetahuan Penggunaan Analgetik pada Pengobatan Sendiri berdasarkan Sosiodemografi pada Masyarakat di Kecamatan Karanganom Kabupaten Klaten. Skripsi; Fakultas Farmasi Universitas Muhammadiyah, Surakarta. 